\title{
Mycobacterium avium Complex (MAC) in Water Distribution Systems and Household Plumbing in the United States
}

\author{
Joseph O. Falkinham III (D) \\ Department of Biological Sciences, Virginia Tech, Blacksburg, VA 24061, USA; jofiii@vt.edu; Tel.: +1-540-231-5931
}

Received: 28 October 2020; Accepted: 23 November 2020; Published: 28 November 2020

\begin{abstract}
Members of the Mycobacterium avium complex (MAC) are waterborne, opportunistic pathogens whose characteristics make urban water distribution systems and household plumbing ideal habitats for their survival, persistence and growth. Rather than contaminants, MAC are colonists of drinking water systems. MAC are normal inhabitants of natural soils and water, and enter drinking water treatment systems through surface sources. A proportion of MAC survive transmission through the treatment plant, and regrow in the distribution system and household plumbing. Once within household plumbing, MAC adhere to surfaces and form biofilms, thus preventing their washout. The thermal tolerance of MAC leads to growth in water heating systems. Stagnation does not reduce MAC numbers, as MAC can grow at low oxygen levels. MAC present challenges to current water monitoring approaches as their numbers do not correlate with E. coli, fecal coliforms or heterotrophic plate count bacteria.
\end{abstract}

Keywords: Mycobacterium avium complex (MAC); disinfectant resistance; oligotrophic growth; growth at low oxygen; thermal tolerance; desiccation tolerance; biofilm formation

\section{Introduction}

The Mycobacterium avium complex (MAC) are waterborne, opportunistic pathogens that cause pulmonary, blood stream and skin infections in susceptible individuals [1]. Currently, it is estimated that there are over 180,000 individuals with pulmonary MAC infections [2]. It is estimated that the cost of treatment of MAC infections is $\$ 500$ million per year in the United States [3]. The MAC currently includes four M. avium subspecies (i.e., avium, silvaticum, hominissuis and paratuberculosis) and seven additional species, with $M$. intracellulare, M. chimaera. M. avium subsp., Hominissuis, M. intracellulare and $M$. chimaera being the major pathogens [4].

MAC are natural inhabitants of soils and surface waters, and enter urban water distribution systems through surface water. As this review will document, distribution systems and premise plumbing are ideal habitats for MAC. Thus, MAC and humans share the same habitats, and the likelihood of MAC-transmission via aerosols is high. Selection for the growth and survival of MAC occurs in water treatment plants, the distribution system and household plumbing. MAC are staggeringly disinfectant-resistant [5], desiccation-resistant [Falkinham, in preparation], grow at low nutrient assimilable organic carbon (AOC) concentrations [6], grow at low oxygen concentrations [7], form biofilms [8] and tolerate high water heater temperatures [9]. MAC are readily aerosolized [10], and pulmonary infections have been traced to showerheads [11-15]. Humans are surrounded by MAC. 


\section{Sources of MAC in Water}

\subsection{Soils, Peat Bogs and Sphagnum Vegetation}

Early work documenting the presence of MAC bacteria in the environment showed their presence in peat bogs associated with sphagnum vegetation [16], and in southeastern coastal acidic brown water swamps of the United States [17]. In truly innovative experiments, it was shown that MAC strains grew in suspensions contained in semipermeable tubes placed in sphagnum vegetation [16]. Furthermore, boreal forest soils have also shown to be a rich source of MAC and other Mycobacterium spp. [18]. As expected, water draining from boreal forest soils had high numbers of MAC and other Mycobacterium spp. [19]. Isolation and enumeration of MAC from soils is difficult, due to their slow growth and requirement for decontamination [20]. As an alternative to isolation from soil and dust, aerosols (dusts) were generated and collected after dropping $100 \mathrm{gm}$ patient soil samples $30 \mathrm{~cm}$ in an enclosed hood. Dust isolates of the same species and 16S rRNA sequence as the patient's isolates were isolated [20].

\subsection{Surface Waters}

It is rare to find a water sample collected from a natural body of water or from a distribution system or premise plumbing that is free from MAC or Mycobacterium spp. MAC cells in surface waters, including southeastern US coastal, brown water and acidic swamps [17], are found in the highest numbers in the surface microlayer [21]. This distribution is likely due to the hydrophobic surface of Mycobacterium cells, which drive the upward movement of cells in the water column.

\subsection{Estuaries}

The Chesapeake and Delaware Bays of the eastern coast of the United States are fed by freshwater rivers and streams, but are subject to tidal inflows of ocean water of high salinity. Both the Chesapeake and Delaware Bays are rich sources of Mycobacterium spp.; predominantly members of MAC [22]. Based on this observation, we measured the growth of MAC strains at different salinities, and discovered that MAC growth was highest at salinities of 1 and 2\%, in brackish water [23]. MAC did not grow in ocean water or estuary waters at salinities of 3\% [23].

\section{Factors Selecting for MAC in the Water Plant}

\subsection{Particulate Reduction}

One of the steps of water treatment is coagulation and sedimentation to remove particulates. As MAC bacteria are hydrophobic and associated with particulates, particulate (turbidity) reduction will also reduce MAC numbers [24]. The hydrophobicity of MAC cells can be easily demonstrated by spotting a small drop of water on cells of any MAC strain collected on a $0.45 \mu \mathrm{m}$ pore size filter paper, i.e., water beads. Quantitative measurement of cell surface hydrophobicity can be made using a goniometer, a telescopic microscope that measures the angle between the surface and a drop of water on the MAC cell surface. MAC contact angles are usually $90^{\circ}$.

Although in treatment plants agents are used to catalyze coagulation and sedimentation, in ponds or lakes with low flow rates, particulates and associated MAC cells would settle to the bottom, thereby reducing MAC cell numbers. However, the non-particle-associated MAC cells would rise to the surface due to hydrophobicity [21] creating an interesting dynamic in the distribution of MAC in the water column, particle-associated MAC at the bottom and free MAC cells in the surface microlayer.

\subsection{Disinfectant-Resistance}

Members of the MAC are staggeringly resistant to chlorine and other disinfectants used in water treatment, such as chloramine and ozone [5]. The standard for measuring disinfection efficacy $\left(\mathrm{CT}_{99.9 \%}\right)$ is the product of chlorine concentration $(\mathrm{mg} / \mathrm{L})$ and the length of exposure (min) to kill $99.9 \%$ (3-logs). 
The $\mathrm{CT}_{99.9 \%}$ for Escherichia coli is 0.05 , while those for MAC strains is 100 [5]. This means that low numbers of MAC cells can pass through the treatment plant process and enter the distribution system, where cell numbers can increase approximately two-fold between the treatment plant and household water meters [24].

\section{Factors Selecting for MAC in Water Distribution Systems}

\subsection{Oligotrophic Growth at Low AOC}

As water leaving the treatment plant is relatively free of Gram-negative waterborne contaminants like E. coli, a proportion of the AOC can be utilized by the MAC cells for growth. In a pilot distribution system, it was shown that a strain of M. avium could grow at AOC levels of $50 \mu \mathrm{g} / \mathrm{L}$ [6]. Furthermore, as a substantial proportion of AOC is humic and fulvic acids, and MAC growth is stimulated by humic and fulvic acids [25], it is not surprising that MAC numbers increase in distribution systems and premise plumbing. MAC are oligotrophic, consistent with their numbers and ubiquity in natural and drinking water.

\subsection{Surface Adherence and Biofilm Formation}

As members of the MAC are slow growing, namely one generation per day at $37^{\circ} \mathrm{C}$ in rich laboratory media, it would be expected that they would be washed out in a flowing system, such as a distribution system or premise plumbing. That they are not is due to surface adherence and biofilm formation. MAC cells rapidly adhere to surfaces used in plumbing: stainless steel, galvanized steel, copper and PVC [8]. In fact, because of the high surface hydrophobicity of MAC cells, the majority of cells in a distribution system or premise plumbing are on surfaces, and not in suspension. For example, upon inoculation of a heater-cooler water reservoir, $99.9 \%$ of the $M$. chimaera cells were no longer in suspension, but adhering to the walls of the reservoir, pipes, tubes and pumps in the heater-cooler [26]. This is why it is recommended to collect biofilm samples when looking for MAC sources in the environment, hospitals or homes.

Growth in biofilms has another benefit for MAC cells in distribution systems and premise plumbing: disinfectant-resistance. MAC cells in biofilms are even more resistant than cells in suspension [27]. Two phenomena are responsible: (1) chlorine and other disinfectants not penetrating the biofilm [28]; and MAC cells grown in biofilms, yet exposed to disinfectant in suspension, being more resistant to chlorine than cells grown only in suspension [27]. This latter characteristic attests to the ability of MAC strains to adapt to stressful conditions due to prior growth conditions; in this case, growth in biofilms.

\subsection{Growth in Amoeba and Protozoa}

Free-living amoeba and protozoa are capable of feeding on bacteria, particularly bacteria on surfaces and in biofilms. Members of MAC have adapted to that predation by surviving and growing in amoeba [29] and protozoa [30]. This is a typical characteristic of many of the opportunistic premise plumbing pathogens [28]. Thus, the presence of amoeba and protozoa in distribution systems and premise plumbing leads to increases in MAC numbers, as opposed to decreases. Growth and survival in amoeba and protozoa can be used as a means to isolate MAC and other Mycobacterium spp. cells in environmental samples. Inoculation of a water or biofilm sample with starved cells of either an amoebae or protozoan followed by incubation can lead to recovery of a wider variety of Mycobacterium spp. cells (Falkinham, unpublished).

\section{Factors Selecting for MAC in Premise Plumbing}

\subsection{MAC in Premise Plumbing}

MAC have been isolated from bathrooms [11-15,31] and showerheads [14,15]. Furthermore, M. avium isolates from the showerhead and the infected patient using the shower were shown to be 
clonally related [15]. Evidence that isolation of M. avium from shower aerosols had a high odds ratio associated with $M$. avium pulmonary disease, which indicates that showers and their aerosols are significant sources of MAC [15].

\subsection{Water Heating and MAC Thermal Tolerance}

Upon entering a building, hospital, apartment or condominium building or single-family residence, a proportion of the water is heated. Depending on the set temperature of the water heater, MAC cells will be killing or proliferate. In homes with water heaters set at $125^{\circ} \mathrm{F}\left(50{ }^{\circ} \mathrm{C}\right)$ or lower, Mycobacterium spp. were recovered [32]. If the water heater was set at $130^{\circ} \mathrm{F}\left(55^{\circ} \mathrm{C}\right)$ or higher, Mycobacterium spp. were rarely recovered [32]. In 10 homes of M. avium-infected patients in Wynnewood, PA (a suburb of Philadelphia) [33], water heater temperatures were raised, and within 8-12 weeks, M. avium could no longer be recovered from biofilm samples [in preparation]. Although the temperature of water in plumbing in the different houses was not always $50^{\circ} \mathrm{C}$ or higher, it was significantly higher than $45{ }^{\circ} \mathrm{C}$ in all. The highest temperature for growth of MAC is $42{ }^{\circ} \mathrm{C}$, a unique property of only M. avium [Falkinham, unpublished].

In addition to water heaters providing warmer temperatures for the growth of MAC cells, the recirculation of heated water leads to even higher numbers of MAC cells. The highest numbers of MAC (i.e., 100,000 colony-forming units/mL water) have been recovered from high-rise apartment and condominium buildings in New York and other high-density cities [34].

\subsection{Water Age, Stagnation and MAC Growth at Low Oxygen Levels}

In single-family homes, apartments and condominiums, warm water is most likely circulated in the mornings and evenings. During the majority of each day, water does not circulate and can become stagnant. MAC cells are capable of growth at low oxygen levels (6 and 12\% oxygen) encountered in stagnant areas of plumbing [7]. Furthermore, residual disinfectant levels fall to levels that fail to inhibit the growth of most bacteria. Unoccupied residences (e.g., second homes), hotels and hospital wings and wards that are not used also have stagnant water with high numbers of MAC. Entering a second home should be followed immediately by a complete flushing of the entire water system in the building. This has been recommended for building managers of offices that have been closed due to the COVID-19 pandemic [35].

\section{Monitoring for MAC}

\subsection{MAC Are in Most Households}

Unless there is a compelling reason, there is no need to monitor or test premise plumbing for the presence of members of the MAC. Surveys across the United States have shown that $70 \%$ of showerheads have Mycobacterium spp., of which 30\% have MAC [11-15]. Studies focusing specifically on mycobacteria in showerheads confirmed their presence, and identified microorganisms whose presence coincided with mycobacteria [11-14]. The rapid detection of MAC is possible using DNA amplification methods, but that information cannot be employed to compare DNA fingerprints of patient and environment isolates. Fingerprint comparisons require isolation of cultured bacteria from both the patient and their environment. If a novel source is suspected, such as a humidifier or refrigerator water tap, sampling and culture isolation is justified.

\subsection{Lack of Dose Response}

Another reason for not mounting a MAC monitoring program is that there are not established, proven or accepted values for MAC dose-response. In the absence of dose-response data, the significance of counts of MAC cells in an environmental water sample cannot be judged. There are simply no action levels. 


\subsection{Lack of Correlation with Common Water Microbiology Measures}

To date, there have been no demonstrated correlations between E. coli or fecal coliform and MAC numbers in drinking water samples [24]. The reason is that the origin of MAC is the water; they are not contaminants. Furthermore, unlike E. coli or fecal coliform numbers, which fall as the distance between the source of contamination and collection point increases due to flow or time, MAC numbers increase as witness to their two-fold increase in distribution systems between treatment plant and residence [24]. Although MAC bacteria are heterotrophs, there are no correlations between the heterotrophic plate count (HPC) and MAC numbers. This is due in part to the fact that HPC counts are made after 2-3 days, long before MAC colonies appear to be counted.

\section{Conclusions}

There is little doubt that the M. avium complex (MAC) surrounds humans, as it is present in household plumbing. MAC are ideally adapted for survival, persistence and growth in household plumbing. As MAC numbers do not correlate with standard water quality measures, novel methods must be developed if MAC are to be monitored in distribution systems and household plumbing.

Funding: This research received no external funding.

Conflicts of Interest: The author declares no conflict of interest.

\section{References}

1. Maras, T.K.; Daley, C.L. Epidemiology of human pulmonary infection with nontuberculous mycobacteria. Clin. Chest Med. 2002, 23, 553-567. [CrossRef]

2. Billinger, M.E.; Olivier, K.N.; Viboud, C.; De Oca, R.M.; Steiner, C.; Holland, S.M.; Prevots, D.R. Nontuberculous Mycobacteria-associated Lung Disease in Hospitalized Persons, United States, 1998-2005. Emerg. Infect. Dis. 2009, 15, 1562-1569. [CrossRef] [PubMed]

3. Collier, S.A.; Stockman, L.J.; Hicks, L.A.; Garrison, L.E.; Zhou, FJ.; Beach, M.J. Direct healthcare costs of selected diseases primarily or partially transmitted by water. Epidemiol. Infect. 2012, 140, 2003-2013. [CrossRef] [PubMed]

4. Tortoli, E. Impact of Genotypic Studies on Mycobacterial Taxonomy: The New Mycobacteria of the 1990s. Clin. Microbiol. Rev. 2003, 16, 319-354. [CrossRef]

5. Taylor, R.M.; Norton, C.D.; LeChevallier, M.W.; Falkinham, J.O. Susceptibility of Mycobacterium avium, Mycobacterium intracellulare, and Mycobacterium scrofulaceum to chlorine, chloramine, chlorine dioxide, and ozone. Appl. Environ. Microbiol. 2000, 66, 1702-1705. [CrossRef]

6. Norton, C.D.; Lechevallier, M.W.; Falkinham, J.O. Survival of Mycobacterium avium in a model distribution system. Water Res. 2004, 38, 1457-1466. [CrossRef]

7. Lewis, A.H.; Falkinham, J.O. Microaerobic growth and anaerobic survival of Mycobacterium avium, Mycobacterium intracellulare and Mycobacterium scrofulaceum. Int. J. Mycobacteriol. 2015, 4, 25-30. [CrossRef]

8. Mullis, S.N.; Falkinham, J.O. Adherence and biofilm formation of Mycobacterium avium and Mycobacterium abscessus to household plumbing materials. J. Appl. Microbiol. 2013, 115, 908-914. [CrossRef]

9. Guenette, S.; Williams, M.D.; Falkinham, J.O. Growth temperature, trehalose, and susceptibility to heat in Mycobacterium avium. Pathogens 2020, 9, 657. [CrossRef]

10. Parker, B.C.; Ford, M.A.; Gruft, H.; Falkinham, J.O. Epidemiology of infection by nontuberculous mycobacteria. IV. Preferential aerosolization of Mycobacterium intracellulare from natural waters. Am. Rev. Respir. Dis. $1983,128,652-656$.

11. Falkinham, I.J.O.; Iseman, M.D.; De Haas, P.; Van Soolingen, D. Mycobacterium avium in a shower linked to pulmonary disease. J. Water Health 2008, 6, 209-213. [CrossRef] [PubMed]

12. Feazel, L.M.; Baumgartner, L.K.; Peterson, K.L.; Frank, D.N.; Harris, J.K.; Pace, N.R. Opportunistic pathogens enriched in showerhead biofilms. Proc. Natl. Acad. Sci. USA 2009, 106, 16393-16399. [CrossRef] 
13. Arikawa, K.; Ichijo, T.; Nakajima, S.; Nishiuchi, Y.; Yano, H.; Tamaru, A.; Yoshida, S.; Maruyama, F.; Ota, A.; Nasu, M.; et al. Genetic relatedness of Mycobacterium avium subsp. hominissuis isolates from bathrooms of healthy volunteers, rivers, and soils in Japan with human clinical isolates from different geographical areas. Infect. Genet. Evol. 2019, 74, 103923. [CrossRef] [PubMed]

14. Gebert, M.J.; Delgado-Baquerizo, M.; Oliverio, A.M.; Webster, T.M.; Nichols, L.M.; Honda, J.R.; Chan, E.D.; Adjemian, J.; Dunn, R.R.; Fierer, N. Ecological Analyses of Mycobacteria in Showerhead Biofilms and Their Relevance to Human Health. mBio 2018, 9, 01614-18. [CrossRef] [PubMed]

15. Tzou, C.L.; Dirac, M.A.; Becker, A.L.; Beck, N.K.; Weigel, K.M.; Meschke, J.S.; Cangelosi, G.A. Association between Mycobacterium avium Complex Pulmonary Disease and Mycobacteria in Home Water and Soil. Ann. Am. Thorac. Soc. 2020, 17, 57-62. [CrossRef] [PubMed]

16. Kazda, J.; Pavlík, I.; Falkinham, J.O., III; Hruska, K. The Ecology of Mycobacteria; Kluwer Academic Publisher: Dordrecht, Germany, 2009.

17. Kirschner, R.A.; Parker, B.C.; Falkinham, J.O. Epidemiology of Infection by Nontuberculous Mycobacteria: Mycobacterium avium, Mycobacterium intracellulare, and Mycobacterium scrofulaceum in Acid, Brown-Water Swamps of the Southeastern United States and Their Association with Environmental Variables. Am. Rev. Respir. Dis. 1992, 145, 271-275. [CrossRef] [PubMed]

18. Iivanainen, E.K.; Martikainen, P.J.; Räisäinen, M.J.; Katila, M.-L. Mycobacteria in boreal coniferous forest soils. FEMS Microbiol. Ecol. 1997, 23, 325-332. [CrossRef]

19. Iivanainen, E.K.; Sallantaus, T.; Katila, M.-L.; Martikainen, P.J. Mycobacteria in Runoff Waters from Natural and Drained Peatlands. J. Environ. Qual. 1999, 28, 1226-1234. [CrossRef]

20. De Groot, M.A.; Pace, N.R.; Fulton, K.; Falkinham, J.O. Relationships between Mycobacterium isolates from patients with pulmonary mycobacterial infection and potting soils. Appl. Environ. Microbiol. 2006, 72, 7062-7606. [CrossRef]

21. Roguet, A.; Therial, C.; Saad, M.; Boudahmane, L.; Moulin, L.; Lucas, F.S. High mycobacterial diversity in recreational lakes. Antonie Leeuwenhoek 2016, 109, 619-631. [CrossRef]

22. Falkinham, J.O; Parker, B.C.; Gruft, H. Epidemiology of infection by nontuberculous mycobacteria. I. Geographic distribution in the eastern United States. Am. Rev. Respir. Dis. 1980, 121, 931-937. [PubMed]

23. George, K.L.; Parker, B.C.; Gruft, H.; Falkinham, J.O. Epidemiology of infection by nontuberculous mycobacteria. II. Growth and survival in natural waters. Am. Rev. Respir. Dis. 1980, 122, 89-94. [PubMed]

24. Falkinham, J.O.; Norton, C.D.; Lechevallier, M.W. Factors Influencing Numbers of Mycobacterium avium, Mycobacterium intracellulare, and Other Mycobacteria in Drinking Water Distribution Systems. Appl. Environ. Microbiol. 2001, 67, 1225-1231. [CrossRef] [PubMed]

25. Kirschner, R.A.; Parker, B.C.; Falkinham, J.O. Humic and fulvic acids stimulate the growth of Mycobacterium avium. FEMS Microbiol. Ecol. 1999, 30, 327-332. [CrossRef] [PubMed]

26. Falkinham, J.O. Disinfection and cleaning of heater-cooler units: Suspension and biofilm-killing. J. Hosp. Infect. 2020, 105, 552-557. [CrossRef] [PubMed]

27. Steed, K.A.; Falkinham, J.O. Effect of Growth in Biofilms on Chlorine Susceptibility of Mycobacterium avium and Mycobacterium intracellulare. Appl. Environ. Microbiol. 2006, 72, 4007-4011. [CrossRef]

28. De Beer, D.; Srinivasan, R.; Stewart, P.S. Direct measurement of chlorine penetration into biofilms during disinfection. Appl. Environ. Microbiol. 1994, 60, 4339-4344. [CrossRef]

29. Thomas, V.; Loret, J.F.; Jousset, M.; Greub, G. Biodiversity of amoebae and amoebae-resisting bacteria in a drinking water treatment plant. Environ. Microbiol. 2008, 10, 2728-2745. [CrossRef]

30. Strahl, E.D.; Gillaspy, G.E.; Falkinham, J.O. Fluorescent acid-fast microscopy for measuring phagocytosis of Mycobacterium avium, Mycobacterium intracellulare, and Mycobacterium scrofulaceum by Tetrahymena pyriformis and their intracellular growth. Appl. Environ. Microbiol. 2001, 67, 4432-4439. [CrossRef]

31. Nishiuchi, Y.; Iwamoto, T.; Maruyama, F. Infection Sources of a Common Non-tuberculous Mycobacterial Pathogen, Mycobacterium avium Complex. Front. Med. 2017, 4, 27. [CrossRef]

32. Falkinham, J.O. Nontuberculous Mycobacteria from Household Plumbing of Patients with Nontuberculous Mycobacteria Disease. Emerg. Infect. Dis. 2011, 17, 419-424. [CrossRef] [PubMed]

33. Lande, L.; Alexander, D.C.; Wallace, R.J.; Kwait, R.; Iakhiaeva, E.; Williams, M.; Cameron, A.D.S.; Olshefsky, S.; Devon, R.; Vasireddy, R.; et al. Mycobacterium avium in Community and Household Water, Suburban Philadelphia, Pennsylvania, USA, 2010-2012. Emerg. Infect. Dis. 2019, 25, 473-481. [CrossRef] [PubMed] 
34. Tichenor, W.S.; Thurlow, J.; McNulty, S.; Brown-Elliott, B.A.; Wallace, R.J.; Falkinham, J.O. Nontuberculous Mycobacteria in Household Plumbing as Possible Cause of Chronic Rhinosinusitis. Emerg. Infect. Dis. 2012, 18, 1612-1617. [CrossRef] [PubMed]

35. Proctor, C.R.; Rhoads, W.J.; Keane, T.; Salehi, M.; Hamilton, K.A.; Pieper, K.J.; Cwiertny, D.M.; Prévost, M.; Whelton, A.J. Considerations for large building water quality after extended stagnation. AWWA Water Sci. 2020, 2. [CrossRef]

Publisher's Note: MDPI stays neutral with regard to jurisdictional claims in published maps and institutional affiliations.

(C) 2020 by the author. Licensee MDPI, Basel, Switzerland. This article is an open access article distributed under the terms and conditions of the Creative Commons Attribution (CC BY) license (http://creativecommons.org/licenses/by/4.0/). 